Sakkara. Mr. Emery is above all an excavator, with a reputation for careful and painstaking thoroughness and detail, and for his beautiful architectural plans and drawings. He possesses to a special degree the experience and capacity to carry on the great Petrie tradition of excavation and training in field archæology. It is much to be hoped that, when conditions in Egypt permit, the funds will be found to permit him to continue his supremely important work at Sakkara.

\section{The Newcomen Society: Dr. H. W. Dickinson}

AT the annual general meeting of the Newcomen Society, held at the Institution of Civil Engineers on November 21, when Mr. J. Foster Petree was elected president in succession to Dr. C. H. Desch, the Society conferred the title of 'secretary emeritus' on Dr. Henry Winram Dickinson, for his long and devoted services to the Society. Founded in 1920, the Society has steadily pursued its object of furthering the study of the history of engineering and technology, and has gained a world-wide recognition, by the reading of papers, the publication of 'I'ransactions, the holding of summer meetings in various centres and in many other ways. International in character, the parent Society has now a membership of four hundred, while the North American affiliated Society has more than twelve thousand members. The formation of this vigorous offshoot was due to visits of Dr. Dickinson to the United States, during one of which he was awarded the honorary degree of Eng.D. by Lehigh University. Though all students of technological history are familiar with the Society's Transactions, it is generally admitted that the success of the Society is mainly due to the labours of Dr. Dickinson, whether as secretary, president and editor, or as its representative on occasions at home and abroad. Born at Ulverston, Lancashire, in August 1870, Dr. Dickinson, after attending Manchester Grammar School, was trained as a mechanical engineer. In 1895 he joined the staff of the Science Museum, serving in turn under General Festing, Iseac Lest, Sir Francis Ogilvie and Sir Henry Lyons. He retired in 1930, after holding the rank of keeper for many years. He has published books on Fulton, Watt, Boulton and Trevithick and the steam engine, while he has contributed more than a score of papers to the Newcomen Society, covering a very wide range of subjects. Though advancing years now cause him to relax his efforts for the Society, his numerous friends will look forward to his long enjoying the distinction he has so well earned.

British Scientific Instrument Research Association : Mr. W. D. Haigh

Mr. W. D. Haigh, who has been connected with the British Scientific Instrument Research Association almost since its formation in 1918, was the first member of the research staff and, in recent years, the superintendent of the laboratories. On October 31, 1951, he retired from the Association, having reached the age of sixty-five. At a luncheon which preceded the Council meeting of the Association on October 30, Mr. Haigh was the guest, and Sir Ronald Weeks, the chairman, and Mr. A. J. Philpot, the director of research and secretary, paid tributes to Mr. Haigh's unswerving loyalty to the Association and to the excellence of his past work. In the November issue (6. No. 11; 1951) of the Bulletin of the Association, mention is made of some of the fields of research in which Mr. Haigh has made important contributions.
These include abrasives, radioactive paints, solders, glasses and, together with his brother, photographic graticules.

\section{United States National Science Foundation}

The Budget recommended by the President of the United States for the first year of operation of the National Science Foundation was 14 million dollars; but this was reduced by the House Committee on Appropriations in August to 300,000 dollars, the Committee refusing funds for the two major programmes of the Foundation, namely, support of basic research and the fellowship programme for training scientific man-power, on the ground that their early aid in the present emergency was not very tangible. Dr. A. J. Waterman, director of the Foundation, stated at a meeting sponsored by the American Institute of Biological Science at Minneapolis on September 10 that all active planning and recruiting by the Foundation had accordingly been suspended. Dr. Waterman added that the public did not yet appear to understand or appreciate the meaning of basic research and the extent to which scientific progress depends upon the constant flow of new ideas from this source. The Foundation had been given the specific responsibility of developing a national policy and supporting basic research and oducation in the sciences and was also to serve as a clearinghouse for information on scientific man-power and general scientific activity in the United States. Support of basic research and education in the sciences, continued Dr. Waterman, was its primary mission, and both were in some danger of neglect.

It was announced, however, on November 4 that the appropriation for the National Science Foundation has been restored to $3 \frac{1}{2}$ million dollars under the Supplementary Appropriations Act of 1952, and according to Dr. Waterman about $1 \frac{1}{2}$ million dollars will be allocated for the support of basic research in biology, medicine, mathematics, the physical sciences and engineering; about $1,350,000$ dollars for the training of scientific man-power; and the balance for development of a national policy for the promotion of basie research and education in the sciences, for the wider dissemination of scientific information, and for other services including support of the National Scientific Register, now established in the Office of Education. Basic scientific research will usually be supported by means of research grants, and approximately 400 graduate fellowships will be awarded for the academic year 1952-53 in the mathe matical, physical, medical, biological and engineering sciences. No awards will be made for study in clinical medicine, olthough applications will be considered from medical students who wish to prepare for careers in medical research. Selection of Fellows will be made solely on the basis of ability, and will be carried out by the National Research Council.

\section{Overseas Work of the British Council}

IN the summary published in Nature of December 1, p. 947, of the activities of the British Council, reference is made to the possibility of overlapping occurring with the work of other bodies in presenting the British point of view. Mr. Paul Reed, information officer of the Council, has pointed out that, under a Cabinet decision of 1946, the activities of the British Council in foreign countries have been confined to cultural and educational work, the Council being empowered to deal with general subjects when approaching university teachers, students and similar 